\title{
Clinical and biochemical findings in 7 patients with X-linked adrenoleukodystrophy treated with Lorenzo's Oil
}

\author{
Carmen R. Vargas $^{l}$, Alethéa G. Barschak ${ }^{l}$, Daniella M. Coelhol, Vivian Furlanetto ${ }^{I}$, Carolina F.M. de Souza , \\ Simone M. Karam ${ }^{1}$, Laura Jardim ${ }^{1}$, Moacir Wajner ${ }^{1,2}$ and Roberto Giugliani ${ }^{1,2}$
}

\begin{abstract}
$\mathrm{X}$-Linked adrenoleukodystrophy (X-ALD) is a hereditary disorder of the peroxisomal metabolism biochemically characterized by the accumulation of very long chain fatty acids (VLCFA) in tissues and biological fluids. The major accumulated acids are hexacosanoic acid $\left(\mathrm{C}_{26: 0}\right)$ and tetracosanoic acid $\left(\mathrm{C}_{24: 0}\right)$. The disorder is characterized clinically by central and peripheral demyelination and adrenal insufficiency closely related to the accumulation of fatty acids. The incidence of X-ALD is estimated to be 1:25,000 males. At least six phenotypes can be distinguished. The most common phenotypes are childhood cerebral ALD and adrenomyeloneuropathy (AMN). The recommended therapy consists of the use of the glyceroltrioleate/glyceroltrierucate (GTO/GTE) mixture, known as Lorenzo's Oil, combined with a VLCFA-poor diet. There are alternative treatments such as bone marrow transplantation and immunosuppression, as well as the use of lovastatin and sodium phenylacetate. In the present study we report the clinical and biochemical course of 7 male patients with X-ALD treated with Lorenzo's Oil and a VLCFA-restricted diet. Treatment produced 50\% reduction in $\mathrm{C}_{26: 0}$ and $42.8 \%$ reduction in the $\mathrm{C}_{26: 0} /$ $\mathrm{C}_{22: 0}$ ratio. Most patients remained clinically well, although approximately $30 \%$ of them presented a rapid clinical deterioration. The results showed a poor biochemical-clinical correlation for treatment, indicating that new therapies for X-ALD are needed in order to obtain a better prognosis for patients.
\end{abstract}

\section{INTRODUCTION}

Adrenoleukodystrophy (X-ALD), the most common peroxisomal disease, is an X-linked metabolic disorder with an estimated frequency of 1:25,000 males (Wanders et al., 1993, 1995; Ruiz et al., 1996; Geel et al., 1997; Moser, 1997). Peroxisomes catalyze essential metabolic reactions (Wanders et al., 1993, 1995). Peroxisomal diseases can be classified into three groups according to the extent of loss of peroxisomal function: generalized, multiple or simple (Wanders et al., 1993, 1995; Geel et al., 1997). XALD is included in the last group since, in this case, peroxisomes are unable to perform $\beta$-oxidation (Wanders et al., 1995; Geel et al., 1997), resulting in impaired shortening of fatty acid chains and their derivatives (Wanders $e t$ al., 1993, 1995).

$\mathrm{X}$-ALD is characterized biochemically by the accumulation of very long chain fatty acids (VLCFA) in tissues and biological fluids (Moser et al., 1994; Scriver et al., 1995; Moser, 1997; Yamada et al., 1999). The major accumulated saturated fatty acids are hexacosanoic acid $\left(\mathrm{C}_{26: 0}\right)$ and tetracosanoic acid $\left(\mathrm{C}_{24: 0}\right)$ (Moser et al., 1991; Korenke et al., 1995). The increased concentrations of these metabolites cause progressive demyelination of white matter in the central nervous system and adrenal insufficiency (Wanders et al., 1992; Ruiz, 1996; Moser, 1997).

A defect in the lignoceroyl coenzyme A ligase (Moser et al., 1994; Moser, 1995) causes the accumulation of VLCFA that are not oxidized in the peroxisomes (Moser $e t$ al., 1994; Scriver et al., 1995; Moser, 1995, 1997). Mapping and isolation of the X-ALD gene have shown that the gene encodes a peroxisomal membrane protein, ALD protein (ALDP), which belongs to the ATP-bound carrier protein superfamily (Moser et al., 1994; Moser, 1995, 1997; Yamada et al., 1999). These observations indicated that this protein is somehow involved in the process of VLCFA oxidation (Moser et al., 1994; Moser, 1997).

$\mathrm{X}$-ALD is clinically heterogeneous including different phenotypes (i.e., childhood cerebral form (ALD), juvenile cerebral form, adult cerebral form, adrenomyeloneuropathy (AMN), isolated Addison disease, and asymptomatic patients) (Moser et al., 1991; Scriver et al., 1995; Moser, 1995, 1997; Geel et al., 1997) reported within the same family (Moser et al., 1991, 1994; Scriver et al., 1995; Korenke et al., 1995; Geel et al., 1997; Moser, 1997). The most common clinical forms are ALD and AMN. ALD manifests clinically before 10 years of age and involves a rapid progression of neurologic symptoms, leading to a vegetative state of the patient, often within 3 years (Moser et al., 1991, 1994; Scriver et al., 1995; Korenke et al., 1995; Moser, 1997). AMN appears between 20 and 40 years of age and is characterized by progressive paraparesis involving disorders of the spinal cord (Moser et al., 1991; Korenke et al., 1995; Geel et al., 1997; Moser, 1997). Ap-

${ }^{1}$ Serviço de Genética Médica, Hospital de Clínicas de Porto Alegre,

Rua Ramiro Barcelos, 2350, 90035-003 Porto Alegre, RS, Brasil. Send correspondence to C.R.V.

${ }^{2}$ Departamento de Bioquímica, UFRGS, Porto Alegre, RS, Brasil. 
proximately $50 \%$ of AMN patients show cerebral involvement (Moser et al., 1991; Geel et al., 1997; Moser, 1997).

The first treatment of X-ALD consisted of restricted ingestion of VLCFA. However, this diet did not succeed since VLCFA are also produced endogenously (Scriver $e t$ al., 1995; Moser, 1995, 1997). A diet combining VLCFA restriction and ingestion of monounsaturated oleic acid (glyceroltrioleate, GTO) was proposed and was found to reduce plasma $\mathrm{C}_{26: 0}$ levels by $50 \%$ within 4 months in XALD patients (Scriver et al., 1995; Moser, 1995, 1997). It was later demonstrated that a mixture of monounsaturated erucic acid (glyceroltrierucate, GTE) with GTO at a 4:1 proportion, called Lorenzo's Oil, combined with a VLCFApoor diet, normalized plasma $\mathrm{C}_{26: 0}$ levels within one month (Scriver et al., 1995; Moser, 1995, 1997). After a few years of study, however, the effectiveness of treatment with Lorenzo's Oil was questioned, since it did not prevent the progression of preexisting neurologic symptoms (Scriver et al., 1995; Geel et al., 1997; Restuccia et al., 1999).

The effectiveness of this therapy for patients affected with the X-ALD is disputed. To further investigate this controversy, we evaluated the clinical and biochemical course of 7 Brazilian patients treated with Lorenzo's Oil and a VLCFA-restricted diet.

\section{MATERIAL AND METHODS}

\section{Patients and controls}

We evaluated 7 patients with X-ALD under treatment with a VLCFA-poor diet and Lorenzo's Oil. The mean age of ALD patients at the time of diagnosis was 10 years and AMN patients were 29 years old. A total of 40 blood collections were performed to determine plasma VLCFA. A group of 30 normal individuals was also studied to determine normal values. The patient and control groups were of comparable age ( 7 to 38 years). Blood was collected in the presence of heparin, and plasma was separated and stored frozen at $-20^{\circ} \mathrm{C}$ until the time of analysis. The study was conducted according to the recommendations of the Ethics Committee of the University Hospital of Porto Alegre and all patients gave written informed consent to participate.

\section{Methods}

VLCFA were analyzed by the technique of Moser and Moser, 1991. A $25 \mu \mathrm{l}$ volume of the internal standard $\left(\mathrm{C}_{27: 0}\right.$-heptacosanoic acid) was added to $100 \mu \mathrm{l}$ of plasma and VLCFA were extracted with a chloroform:ethanol mixture (1:1). After centrifugation, the supernatant was mixed with distilled water and chloroform to remove the precipitated protein. After a new centrifugation, the lower phase was evaporated with nitrogen vapor $\left(\mathrm{N}_{2}\right)$ and chloroform:methanol $(2: 1)$ was used to redissolve the lipids. Methanol- $\mathrm{HCl}(3 \mathrm{~N})$ was added to each dried total lipid extract and the tubes were thoroughly sealed and kept at $75^{\circ} \mathrm{C}$ for $16 \mathrm{~h}$ for the formation of fatty acid methyl esters, which were then purified by thin-layer chromatography. Plates $(0.25 \mu \mathrm{m}$ silica gel G 20 x 20) were prewashed with chloroform:methanol:acetic acid:water (52:20:7:3) and hexane:ether:acetic acid (90:10:1). After sample application to the plate, the chromatographic run was performed using toluene:ether (97:3) as eluent. After air drying for $16 \mathrm{~h}$, the samples were stained with iodine vapor. The VLCFA methyl esters were extracted from the silica 3 times using hexane. After drying with $\mathrm{N}_{2}$ vapor, the samples were redissolved with $50 \mu \mathrm{l}$ hexane and analyzed by gas chromatography using a Varian apparatus equipped with an HP-5 column (5\% methylphenyl silicone, $0.33 \mu \mathrm{m}$ film thickness, $0.2 \mathrm{~mm}$ inner diameter and $25 \mathrm{~m}$ in length), a flame ionization detector, and an injector split/splitless type, using helium as the mobile phase. The concentrations of $\mathrm{C}_{22: 0}$ (docosanoic acid), $\mathrm{C}_{24: 0}$ (tetracosanoic acid) and $\mathrm{C}_{26: 0}$ (hexacosanoic acid) were determined and $\mathrm{C}_{\text {26:0 }} / \mathrm{C}_{22: 0}$ and $\mathrm{C}_{24: 0} / \mathrm{C}_{22: 0}$ ratios were calculated.

\section{Treatment}

The patients in the study were treated with a VLCFArestricted diet and $1.2 \mathrm{ml} \mathrm{kg}^{-1}$ day $^{-1}$ Lorenzo's Oil (Moser et al., 1992; Geel et al., 1997). Doses were tailored based on platelet numbers and plasma VLCFA levels of the individuals. Table I indicates the duration of treatment and the doses of Lorenzo's Oil used by the patients with X-ALD.

Supplementation with multivitamins, minerals and an additional source of essential fatty acids (Moser, 1995), linoleic acid and linolenic acid found in saffron oil and fish oil was recommended. In general, restriction of VLCFA ingestion can be achieved by eating the following foods: non-fatty dairy products, lean beef and pork cuts, chicken without skin and low-fat fish, plus fruits and vegetables. The main foods to be avoided are saturated fats such as industrialized fats (butter, cream, milk, ice cream), fats present in meat and meat derivatives, and vegetable oil.

Table I - Duration of therapy and doses of Lorenzo's Oil used for X-ALD patients under dietary treatment.

\begin{tabular}{|ccc|}
\hline Patients & $\begin{array}{c}\text { Oil dose (1/month) and } \\
\mathrm{ml} \mathrm{kg}^{-1} \text { day }^{-1}\end{array}$ & $\begin{array}{c}\text { Duration of therapy } \\
\text { (months) }\end{array}$ \\
\hline ALD & & \\
1 & 2 and 1.2 & 13 \\
2 & 2 and 1.2 & 33 \\
3 & 1.6 and 1.2 & 18 \\
4 & 2.0 and 1.6 & 6 \\
5 & 3.0 and 2.0 & 12 \\
AMN & 3 and 1.2 & 40 \\
1 & 3 and 1.2 & 27 \\
2 & & \\
\hline
\end{tabular}




\section{RESULTS}

Figure 1 (A, B and C) illustrates the plasma concentration of $\mathrm{C}_{26: 0}$ and the $\mathrm{C}_{26: 0} / \mathrm{C}_{22: 0}$ and $\mathrm{C}_{24: 0} / \mathrm{C}_{22: 0}$ ratios, respectively, during the various phases of patient treatment. Figure $1 \mathrm{~A}$ shows that $\mathrm{C}_{26: 0}$ levels were markedly decreased in all patients after the beginning of treatment and remained relatively close to normal values throughout most of the treatment period. Figure $1 \mathrm{~B}$ shows that the $\mathrm{C}_{26: 0} / \mathrm{C}_{22: 0}$ ratio was reduced in all patients except patient ALD 2 after the beginning of therapy, although this ratio was reduced in this patient during the third phase of treatment. The ratio was reduced to levels closer to normal in all patients.

A wide range of $\mathrm{C}_{24: 0} / \mathrm{C}_{22: 0}$ ratios (Figure $1 \mathrm{C}$ ) was observed throughout treatment in all X-ALD patients, except patient ALD 3 who presented a more consistently normal $\mathrm{C}_{\text {24:0 }} / \mathrm{C}_{22: 0}$ ratio.

Table II describes the clinical history of X-ALD patients under dietary treatment. Most patients showed no major complications during therapy. Gastrointestinal disturbances like vomiting and diarrhea, and low platelet count were common findings. Only one patient had a progressively deteriorating clinical picture, and one death occurred during therapy. All ALD patients (and none AMN patient) had abnormal CT scans.

\section{DISCUSSION}

We describe here our experience with the treatment of 2 patients with AMN and 5 patients with ALD with Lorenzo's Oil and diet. The mean duration of treatment was 21 months. All patients were diagnosed late and started treatment when irreversible neurologic symptoms were already present.

The patients presented high plasma $\mathrm{C}_{26: 0}$ levels and $\mathrm{C}_{26: 0} / \mathrm{C}_{22: 0}$ ratios at the time of diagnosis.

Plasma $\mathrm{C}_{26: 0}$ levels were above $2.86 \mu \mathrm{mol} / \mathrm{l}$ (normal levels: 0.32 to $1.56 \mu \mathrm{mol} / \mathrm{l}$ ) in $62 \%$ of the determinations made in the 7 patients treated for X-ALD during the treatment period. However, plasma $\mathrm{C}_{26: 0}$ levels were drastically reduced in these patients after the onset of treatment, remaining, on average, $58 \%$ below initial values throughout treatment. In the assessment of treatment, it is important to consider the difficulty in complying with a VLCFA-poor diet and in correctly ingesting the oil, a fact that may lead to variations in plasma VLCFA levels during therapy.

Of these patients $57.1 \%$ remained without major complications (ALD patients numbers 2 and 5 and AMN patients numbers 1 and 2, see Table I). During the same period, $28.6 \%$ of the patients (ALD patients numbers 3 and

Figure 1 - A, Plasma $C_{26: 0}$ levels; $B, C_{26: 0} / C_{22: 0}$ ratio, and $C, C_{24: 0} / C_{22: 0}$ ratio of $\mathrm{X}$-ALD patients treated with Lorenzo's Oil at different times. The broken lines indicate the normal ranges. The continuous lines with different symbols indicate the 5 ALD and 2 AMN patients.
A

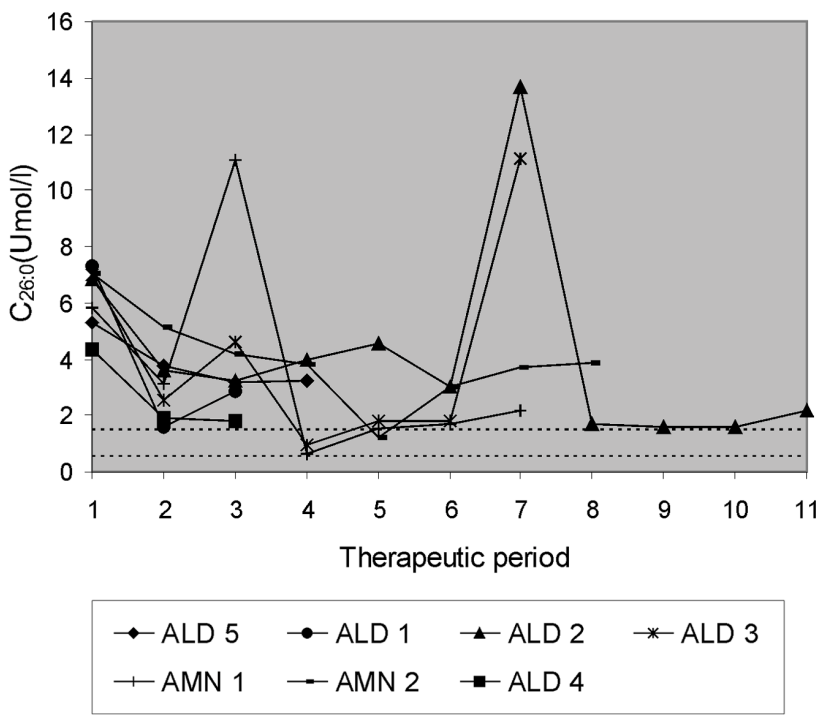

B
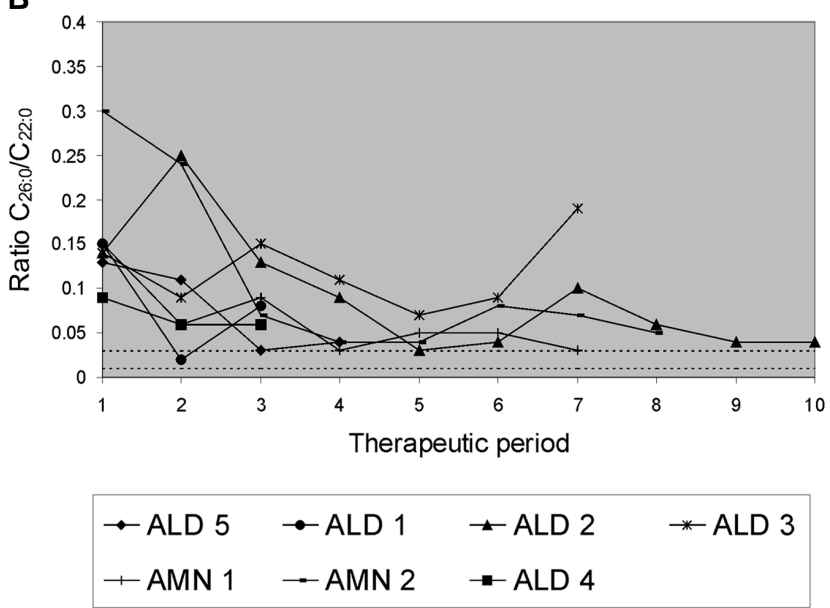

C

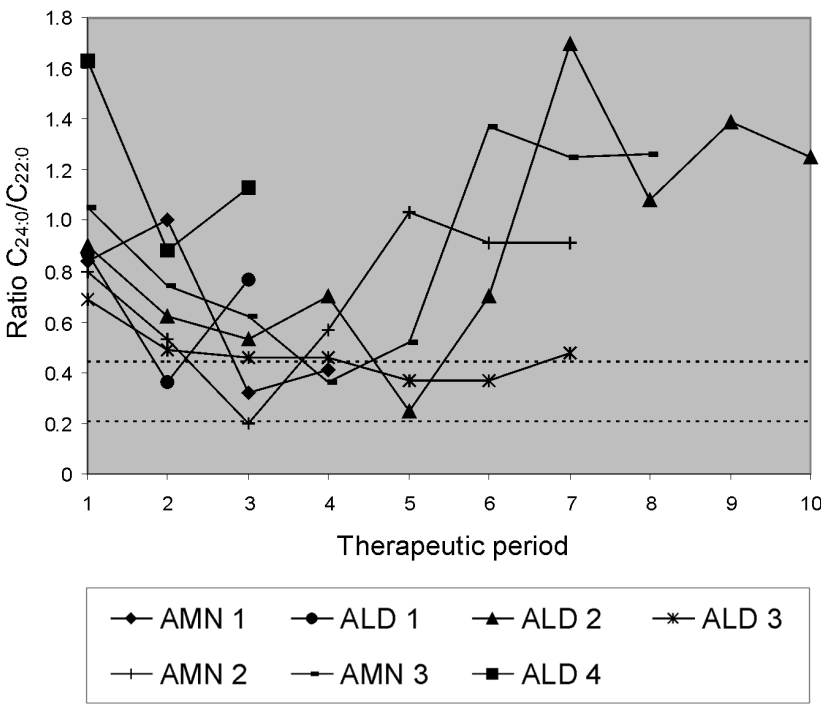


Table II - Situation of X-ALD patients under treatment with Lorenzo's Oil.

\begin{tabular}{|lc|}
\hline Situation & Percentage (\%) \\
\hline No noticeable disease progression or major & \\
complications & 57.1 \\
Slightly worsening in CT image & 14.3 \\
Severe worsening & 14.3 \\
Death & 14.3 \\
\hline
\end{tabular}

4, see Table I) underwent rapid deterioration, with the occurrence of one death. These results show that there is no clear correlation between the biochemical and clinical parameters measured in patients undergoing dietary treatment supplemented with Lorenzo's Oil.

In a study of 50 patients with no neurologic symptoms also treated with GTO/GTE, Moser et al. (1994) observed that $56 \%$ of patients did well during treatment, $14 \%$ showed alterations upon cerebral nuclear magnetic resonance (NMR) image or in cognitive function, whereas in another 14\% the NMR image was significantly worse. In addition, $8 \%$ of the patients showed deteriorating NMR images and mild to moderate behavioral and cognitive function damage. In the remaining $8 \%$ there was a rapid development of the progressive infantile cerebral phenotype. Furthermore, $65 \%$ of the individuals achieved a significant decrease in plasma $\mathrm{C}_{26: 0}$ concentration that remained within normal limits in $40 \%$ of them. In $17 \%$ of the patients there was a small reduction in hexacosanoic acid concentration, while no reduction was observed in the remaining $17 \%$, probably due to their inability to follow the dietary regimen.

Other studies demonstrated that treatment with Lorenzo's Oil was ineffective in changing the clinical course of the disease in 15 Italian and 20 American boys with ALD, who already presented neurologic symptoms at diagnosis (Wanders et al., 1992; Moser et al., 1992). In addition, Korenke et al. (1995) assessed the results of treatment with the GTO/GTE mixture in 16 patients, 7 of them asymptomatic. Three died and 3 showed a worsened clinical course, while the 7 asymptomatic patients remained clinically stable during treatment. Follow-up of these asymptomatic patients showed that in those under dietary treatment a mild neurologic abnormality remained stable for long periods of time. The data suggest that early administration of Lorenzo's Oil reduces the frequency and severity of the subsequent neurologic deficiencies. However, these data should be interpreted with caution since recent studies have indicated that Lorenzo's Oil does not penetrate the brain, a fact raising questions about the therapeutic value of the GTO/GTE mixture. Other studies carried out by Moser (1997) have indicated that, whereas erucic acid is found in post mortem liver and adipose tissue, it is not demonstrable in the brain. Therefore, since erucic acid does not reach the brain in adequate concentrations, it is unlikely that an effect occurs with the currently prescribed dose of Lorenzo's Oil. Other analyses have indicated that $\mathrm{C}_{26: 0}$ levels observed post mortem in cerebral tissue of X-ALD patients treated with Lorenzo's Oil do not differ from those of untreated patients (Moser, 1995).

Recent studies have demonstrated that not only $\mathrm{C}_{24: 0}$ and $\mathrm{C}_{26: 0}$ are elevated in X-ALD, but also the monounsatura-

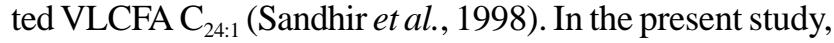
wide variability in the $\mathrm{C}_{24: 0} / \mathrm{C}_{22: 0}$ ratio was observed in most of the patients, probably due to the lack of administration of the essential fatty acids linolenic acid and linoleic acid. Taken together, it seems that treatment based on a special diet combined with Lorenzo's Oil should be reevaluated.

We conclude that new therapies are needed for XALD in order to obtain a better prognosis for the patients and to slow or reverse the progression of symptoms. Other therapies such as bone marrow transplantation or immunosuppression have been used for X-ALD treatment but in most cases without satisfactory results (Scriver et al., 1995; Geel et al., 1997; Moser, 1997). In addition, new drugs such as lovastatin and sodium phenylacetate, which increase peroxisomal $\beta$-oxidation of VLCFA, are being tested in order to normalize tissue VLCFA levels, and appear to provide a more effective clinical response (Singh et al., 1998). Gene therapy also holds promise as a potential future treatment of X-ALD.

\section{RESUMO}

A adrenoleucodistrofia ligada ao X (X-ALD) é uma desordem hereditária do metabolismo peroxissomal, bioquimicamente caracterizada pelo acúmulo de ácidos graxos de cadeia muito longa ("very long chain fatty acids"- VLCFA) em diferentes tecidos e em fluidos biológicos, sendo os principais ácidos acumulados o hexacosanóico $\left(\mathrm{C}_{26: 0}\right)$ e o tetracosanóico $\left(\mathrm{C}_{24: 0}\right)$. $\mathrm{O}$ acúmulo destes ácidos graxos está associado com desmielinização cerebral e insuficiência adrenal. A incidência desta condição é estimada em 1 para 25.000 em homens. Pelo menos seis fenótipos podem ser distinguidos, sendo a adrenoleucodistrofia (ALD) cerebral infantil e a adrenomieloneuropatia (AMN) os mais comuns. O tratamento preconizado consiste na utilização da mistura gliceroltrioleato/ gliceroltrierucato (GTO/GTE), conhecida como Óleo de Lorenzo, combinada com dieta pobre em VLCFA. Existem ainda, terapias alternativas como transplante de medula óssea e imunossupressão, além da utilização de lovastatina e fenilacetato de sódio. Neste trabalho fez-se uma avaliação do tratamento com Óleo de Lorenzo associado à dieta restrita em VLCFA de 7 pacientes homens com $\mathrm{X}$-ALD analisando a evolução clínica e bioquímica. Os pacientes apresentaram uma redução média de $50 \%$ nos valores de $\mathrm{C}_{26: 0} \mathrm{e}$ de $42,8 \%$ na razão $\mathrm{C}_{26: 0} / \mathrm{C}_{22: 0}$ após o início do tratamento. $\mathrm{A}$ maioria dos pacientes permaneceu clinicamente bem e aproximadamente $30 \%$ dos pacientes apresentaram uma progressão rápida no curso clínico da doença. Parece não haver uma clara correlação bioquímico-clínica do tratamento. Os resultados nos mostram que novas terapias mais eficazes para X-ALD são necessárias para que se possa obter um melhor prognóstico da doença com progressão mais lenta dos sintomas apresentados ou mesmo reversão dos sintomas já presentes nos pacientes. 


\section{REFERENCES}

Geel, B.M. van, Assies, J., Wanders, R.J.A. and Barth, P.G. (1997). Xlinked adrenoleukodystrophy: clinical, presentation, diagnosis and therapy. J. Neurol. Neurosurg. Psychiatry 63: 4-14.

Korenke, G.C., Hunneman, D.H., Kohler, J., Stöckler, S., Landmark, K. and Hanefeld, F. (1995). Glyceroltrioleato/glyceroltrierucate therapy in 16 patients with X-chromosomal adrenoleukodystrophy/adrenomyeloneuropathy: effect on clinical, biochemical and neurophysiological parameters. Eur. J. Pediatr. 154: 64-70.

Moser, H.W. (1995). Adrenoleukodystrophy: natural history, treatment and outcome. J. Inherited Metab. Dis. 18: 435-447.

Moser, H.W. (1997). Adrenoleukodystrophy: phenotype, genetics, pathogenesis and therapy. Brain 120: 1485-1508.

Moser, H.W. and Moser, A.B. (1991). Adrenoleukodystrophy. Endocrinol. Metab. Clin. North Am. 20: 297-318

Moser, H.W., Bergin, A., Naidu, S. and Ladenson, P.W. (1991). Adrenoleukodystrophy. Endocrinol. Metab. Clin. North Am. 20: 297-318.

Moser, H.W., Moser, A.B., Smith, K.D., Bergin, A., Borel, J., Shankroff, J., Stine, O.C., Merette, C., Ott, J., Krivit, W. and Shapiro, E. (1992). Adrenoleukodystrophy: Phenotypic variability and implications for therapy. J. Inherited Metab. Dis. 15: 645-664.

Moser, H.W., Kok, F., Neumann, S., Borel, J., Bergin, A., Mostafa, S.D., Panoscha, R., Davoli, C.T., Shankroff, J. and Smith, K.D. (1994). Adrenoleukodystrophy update: Genetics and effect of Lorenzo's Oil therapy in asymptomatic patients. Int. J. Pediatr. 9: 196-204.

Restuccia, D., Lazzaro, V. Di, Valeriani, M., Oliviero, A., Pera, D. Le, Barba, C., Cppa, M., Bertini, E., Capua, M. Di and Tonali, P. (1999). Neurophysiologic follow-up of long-term dietary treatment in adult- onset adrenoleukodystrophy. Neurology 52: 810-815.

Ruiz, M., Pampols, T. and Girós, M. (1996). Glycerol trioleato/glycerol trierucate therapy in X-linked adrenoleukodystrophy: Saturated and unsaturated fatty acids in blood cells. Implications for the follow-up. J. Inherited Metab. Dis. 19: 188-192.

Sandhir, R., Kahn, M., Chahal, A. and Singh, I. (1998). Localization of neuronic acid beta-oxidation in human and rodent peroxisomes. Impaired oxidation in Zellweger syndrome and X-linked adrenoleukodystrophy. J. Lipid Res. 39: 2161-2171.

Scriver, C.R., Beaudet, A.L., Sly, W.S. and Valle, D. (Eds.) (1995). The Metabolic and Molecular Bases of Inherited Disease. 7th edn. McGraw-Hill, New York.

Singh, I., Pahad, K. and Khan, M. (1998). Lovastatin and sodium phenylacetate normalize the levels of very long chain fatty acids in skin fibroblasts of X-adrenoleukodystrophy. FEBS Lett. 426: 342-346.

Wanders, R.J.A., Roermund, C.W.T. van, Lageweg, W., Jakobs, B.S., Schutgens, R.B.H., Nijenhuis, A.A. and Tager, J.M. (1992). X-linked adrenoleukodystrophy: Biochemical diagnosis and enzyme defect. $J$. Inherited Metab. Dis. 15: 634-644.

Wanders, R.J.A., Schutgens, R.B.H., Barth, P.G., Tager, J.M. and Bosch, H. van den (1993). Postnatal diagnosis of peroxisomal disorders: A biochemical approach. Biochemie 75: 269-279.

Wanders, R.J.A., Schutgens, R.B.H. and Barth, P.G. (1995). Peroxisomal disorders: A review. J. Neuropathol. Exp. Neurol. 54: 726-739.

Yamada, T., Taniwaki, T., Shinnoh, N., Uchiyama, A., Shimozawa, N. Ohyagi, Y., Asahara, H. and Kira, J. (1999). Adrenoleukodystrophy protein enhances association of very-long acyl-coenzyme A synthetase with the peroxisome. Neurology 52: 614-616.

(Received July 24, 2000) 
